\title{
新規有核錠（OSDrC）による結腸へのドラッグデリバリー
}

\author{
櫻井雅人, ${ }^{a}$ 尾関有一, ${ }^{b}$ 安藤正樹, ${ }^{b}$ 岡本浩一, ${ }^{a}$ 檀上和美 $*, a$
}

\section{Drug Delivery to the Colon Using a Novel One-Step Dry-Coated Tablets (OSDrC)}

\author{
Masato SAKURAI, ${ }^{a}$ Yuichi OzeKI,${ }^{b}$ Masaki ANDO, ${ }^{b}$ \\ Hirokazu OKAмото, ${ }^{a}$ and Kazumi DANJO*,a \\ ${ }^{a}$ Faculty of Pharmacy, Meijo University, 150 Yagotoyama, Tenpaku-ku, Nagoya, 468-8503, Japan, \\ and ${ }^{b}$ OSDrC Division, Sanwa Kagaku Kenkyusho Co., Ltd., 363 Shiosaki, \\ Hokusei-cho, Inabe City 511-0406, Japan
}

(Received January 19, 2008; Accepted February 21, 2008)

\begin{abstract}
One-step dry-coated tablets (OSDrC), which are useful as colon-targeting drugs, were prepared using Eudragit $\mathrm{L}$ 100-55 (Eud-L) and chitosan (Chit) as an outer layer. The lag time of OSDrC with an outer layer of Eud-L : Chit at a ratio of $3: 1$ in each test medium was greater than the gastric emptying time in the first fluid simulating the stomach and was greater than the small intestine transit time in phosphate buffer $(\mathrm{pH}$ 7.4) simulating the small intestine. Drug-release profiles of OSDrC were evaluated under test conditions considering the amount of gastric acid and bile acid, as well as the amount of fluid in the colon. The lag time of OSDrC was greater than the gastric emptying time in test medium simulating the stomach and greater than the small intestine transit time in test medium simulating the small intestine, although it was affected by the amount of gastric acid and bile acid. Drug release from OSDrC was completed within the colonic transit time in the test medium simulating the colon, although it was affected by the amount of fluid in the colon. Therefore the prepared OSDrC were found to permit drug delivery to the colon.
\end{abstract}

Key words — colon-targeting; one-step dry-coated tablet (OSDrC); chitosan; gastric acid; bile acid; colonic fluid

\section{緒言}

結腸へのドラッグデリバリーは近年，様々な大腸 疾患の局所的治療や消化管上部において消化酵素の 影響を受け易い薬物の体内吸収改善, 及び 1 日 1 回 投与の持続性放出制御製剂の導入など，多くの関心 を集めている。これまでに，消化管内の $\mathrm{pH}$ 変化を 利用した $\mathrm{pH}$ 依存型，消化管通過時間を利用した時 間依存型，腸内細菌の分解酵素を利用した䤉素依存 型など，いくつかの異なるアプローチ1-6) で試みら れてきた.

消化器系の $\mathrm{pH}$ は食事等の影響によりバラツキが あるものの，一般に胃（pH 1.5-5）から回腸（pH 7-8）までは徐々に上昇し, その後, 結腸（pH 5.57）では腸内細菌により糖類が分解されて生じる脂 肪酸のため, 低下する傾向がみられる. ${ }^{7)}$ さらに, 消化管通過時間は胃や大腸ではバラツキが大きいも のの, 小腸通過時間は年齢, 性別に関係なく, さら

\footnotetext{
$a$ 名城大学薬学部, $b$ 三和化学研究所 OSDrC 事業部

*e-mail: danjo@ccmfs.meijo-u.ac.jp
}

に食事，薬物の影響を受けることなく，3-4 h と言 われている.7)

われわれは既に，消化器系の $\mathrm{pH}$ ，及び消化管通 過時間に基づく $\mathrm{pH}$-時間依存型 DDS による結腸 ターゲティング製剂として，外層に腸溶性コーティ ング剂として用いられ，pH 5.5 以上で溶解する Eudragit L 100-55 (Eud-L), 及び酸性条件下で溶解 し, 中性から塩基性においては膨潤し, 結腸内の腸 内細菌により生分解される特性を有する ${ }^{8)}$ ことか ら，結腸薬物送達システムに用いられてきた ${ }^{9-12)}$ キ トサン（Chit）の物理混合物（Eud-L : Chit=3:1） を用い，新規有核錠製造方法である OSDrC-technology (One-Step Dry-Coated tablets technology) 13-16）により調製した有核錠が，胃を想定した溶出 試験液第 1 液（pH 1.2）では胃内容排泄時間（15 $\min -3 \mathrm{~h} ）$ 以上，小腸を想定したリン酸塩緩衝液 (pH 7.4) では小腸通過時間 (3-4h) 以上薬物放出 を抑制し，結腸を想定した第 2 液（pH 6.8）で薬物 を放出した（Fig. 1）ことから，結腸ターゲティン グ製剤として有用であることを報告した. ${ }^{17)}$ 


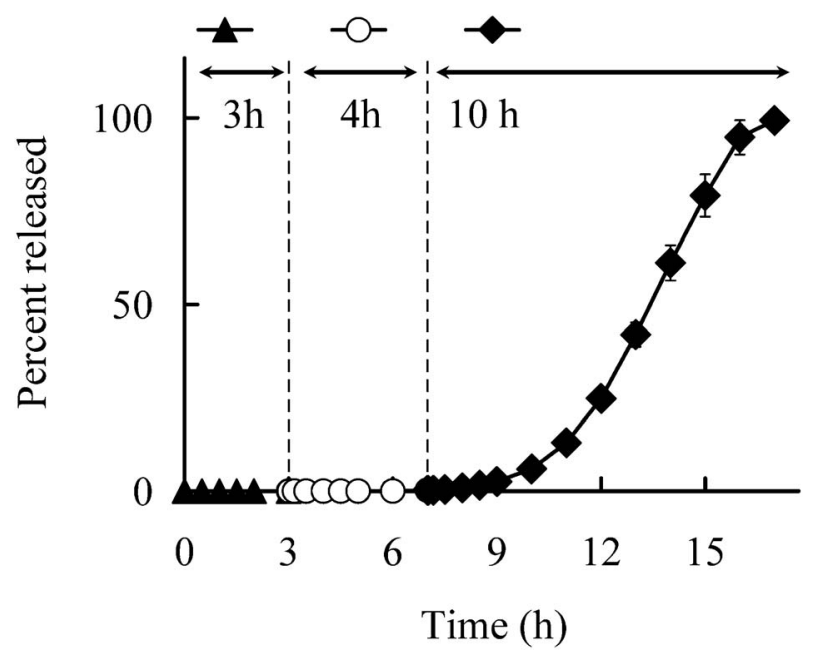

Fig. 1. Drug Release Profiles of 5-FU from OSDrC (Eud-L : Chit $=3: 1)$ in the Sequential $\mathrm{pH}$ Change Method

Each data point represents the mean \pm S.D. of three measurements. Test medium: (ム) 1st fluid (pH 1.2), (O) phosphate buffer $(\mathrm{pH} 7.4),(\diamond) 2 \mathrm{nd}$ fluid $(\mathrm{pH} 6.8)$.

これまでの評価条件は, 前述の標準的な消化器系 の $\mathrm{pH}$ ，及び消化管通過時間に基づき決定した。し かし，消化管には薬物放出挙動に影響を与える生理 的要因が存在する。一般に, 消化管の部位の中で は，胃内の $\mathrm{pH}$ は個体間の変動が大きいことが知ら れており，特に胃酸分泌能は年齢とともに低下し， 50 歳以上の健常成人の約 $60 \%$ が低酸症（pH 2.14.0）あるいは無酸症（pH 4.0 以上）であると言わ れている. ${ }^{18)}$ また，十二指腸には胆汁が肝臓から胆 囊を経て分泌される。肝臓からは 1 日に 0.3-1.01 の胆汁が分泌され, その胆汁中に含まれる胆汁酸濃 度は 3.0-45.0 mmol/1 と言われている. 胆汁酸の界 面活性作用は薬物の水に対する濡れ性改善に寄与 し，しばしば製剤からの薬物放出挙動に影響を与え る. ${ }^{19,20)}$ さらに, 結腸は水分の吸収能力の高い部位 である. 1 日 $2000 \mathrm{ml}$ の電解質液が回盲弁から結腸 に入り，水分の $90 \%$ 以上が結腸から吸収される7)た め，水分の乏しい部位とも言える.

そこで本研究では, 薬物放出挙動の変動要因とし て 1）胃内酸度，2）胆汁酸，3）結腸内水分量を考 慮した評価条件に変更し, その薬物放出性を評価し た．本研究の溶出試験における薬物放出開始遅延時 間（lag time）の目標值を, 胃を想定した試験液で 胃内容排泄時間以上，小腸を想定した試験液で小腸 通過時間以上薬物放出を抑制し, 結腸を想定した試 験液で薬物を放出することを目標とした.

\section{実 験 の 部}

1. 試料有核錠の内核には大腸疾患に適応を 有するモデル薬物として 5-Fluorouracil (5-FU, 和光 純薬)，賦形剤として Lactose (Lac, DMV) を用い, 外層には Eudragit L 100-55 (Eud-L, Degussa) 及び, Chitosan 10 (Chit, 和光純薬) を用いた. 内核・外 層を Table 1 に従い，試験管振とう機（VORTEXGENIE2, エムエス機器）により，それぞれ 10 分間 物理混合して調製した。

2. OSDrCの調製 モデル杵臼（中心杵：直 径 $6 \mathrm{~mm}$, 外杵：直径 $9 \mathrm{~mm}$ ) を用い Table 1 の処 方を, 圧縮圧力 $150 \mathrm{MPa}$, 圧縮速度 $1 \mathrm{~mm} / \mathrm{min}$ 下 で, 万能圧縮試験機（AG-5000D，島津製作所）に より圧縮成形した.

3. 無核錠の調製 無核錠（外層成分のみから なる錠剂）は，OSDrC の調製に用いたモデル杵を 用いて調製した。 中心杵と外杵を一体化した平型の 上下杵（直径 $9 \mathrm{~mm}$ ）を用い, Eud-L, Chit, 及び Table 1 の処方各 $200 \mathrm{mg}$ を, 圧縮圧力 $150 \mathrm{MPa}$, 圧縮速度 $1 \mathrm{~mm} / \mathrm{min}$ 下で, 万能圧縮試験機により 圧縮成形し，錠剂質量 $200 \mathrm{mg}$ の無核錠を得た。

4. 溶出試験溶出試験は第 15 改正日本薬局 方溶出試験法パドル法に準じ, 溶出試験器（NTR3000, 富山産業）を用いて行った。試験液量は 900 $\mathrm{ml}$ ，パドル回転数は $50 \mathrm{rpm}$, 液温は $37 \pm 0.5^{\circ} \mathrm{C}$ と した。 各検体が溶出試験器へ付着あるいは浮上した 場合は，日本薬局方に準じたシンカーを用いた。経 時的に溶出試験液からサンプリングした各検体中の 5-FU 濃度は高速液体クロマトグラフィー（CLASS LC-10，島津製作所）にて測定した。 また，各検体 の lag time は, 溶出曲線が立ち上がるまでの時間 とした.

4-1. 胃内酸度の影響溶出試験液に第 1 液 (pH 1.2)，0.2\% NaCl を溶解した塩酸水溶液（pH 3.0)，および $0.05 \mathrm{~mol} / 1$ リン酸塩緩衝液（ $\mathrm{pH} 4.7 ）$ を用いた。

4-2. 界面活性剂の影響 溶出試験液に 0.01 , $0.1,0.5,1.0 \%$ デオキシコール酸ナトリウム（DC, 和光純薬）を溶解した $0.05 \mathrm{~mol} / 1$ リン酸塩緩衝液 （pH 7.4）を用いた.

4-3. 試験液量の影響 日本薬局方に準じたシ ンカーに入れた検体を, 第 2 液 $10 \mathrm{ml}$ に投入し, 経 
Table 1. Ingredients of OSDrC (Eud-L : Chit $=3: 1)$

\begin{tabular}{cccc}
\hline \hline Material $(\mathrm{mg} / \mathrm{tab})$ & Core & Outer layer & Total \\
\hline 5-FU & 10 & & \\
Lac & 40 & & \\
\hline Eud-L & & 112.5 & \\
Chit & & 37.5 & \\
\hline & 50 & 150 & 200 \\
\hline
\end{tabular}

時的に溶出試験液からサンプリングした．かく汼は 行わず，液温は $37 \pm 0.5^{\circ} \mathrm{C}$ とした.

5. 侵食挙動の評価無核錠を日本薬局方に準 じたシンカー内に入れ, 試験液量 $900 \mathrm{ml}$, パドル 回転数は $50 \mathrm{rpm}$, 液温は $37 \pm 0.5^{\circ} \mathrm{C}$ とした条件下 で，経時的な錠剂質量の減少量を測定した。経時的 に試験液からサンプリングした各錠剤は，事前に質 量を測定したサンプル管に入れ， $70^{\circ} \mathrm{C}, 7$ 日間乾燥 させた，完全に乾燥させた錠剤の質量を測定し，経 時的な錠剤の侵食量を算出した。

5-1. 胃内酸度の影響試験液に第 1 液， $0.2 \%$ $\mathrm{NaCl}$ を溶解した塩酸水溶液（pH 3.0），及び 0.05 $\mathrm{mol} / \mathrm{l}$ リン酸塩緩衝液（ $\mathrm{pH}$ 4.7）を用いた.

5-2. 界面活性剂の影響＼cjkstart試験液に $0.01,1.0 \%$ DC を溶解した $0.05 \mathrm{~mol} / 1$ リン酸塩緩衝液 $(\mathrm{pH} 7.4)$ を用いた。

\section{結果及び考察}

1. 胃内酸度の影響調製した OSDrC は, 胃 を想定した第 1 液において，Chit が溶解すること により生じた細孔から薬物は放出される。17) しか し，胃内の $\mathrm{pH}$ は個体間の変動が大きく，特に胃酸 分泌能は年齢とともに低下し，50 歳以上の健常成 人の約 $60 \%$ が低酸症（pH 2.1-4.0） あるいは無酸 症（pH 4.0 以上）であると言われている.Chit の 溶解は $\mathrm{pH}$ の影響を受けることから，調製した OS$\operatorname{DrC}$ の薬物放出挙動は胃内酸度の影響を受けると 考えられる。そこで，低酸症を想定した $0.2 \%$ $\mathrm{NaCl}$ を溶解した塩酸水溶液（pH 3.0）, 無酸症を 想定した $0.05 \mathrm{~mol} / 1$ リン酸塩緩衝液（pH 4.7）を 用いて薬物放出挙動を評価した。その結果を Fig. 2 に示した。低酸症・無酸症を想定した pH 3.0, 4.7 の lag time は $5 \mathrm{~h}$ と差はなく，胃を想定した第 1 液 の $7 \mathrm{~h}$ と比較して短縮したものの，薬物放出は胃内

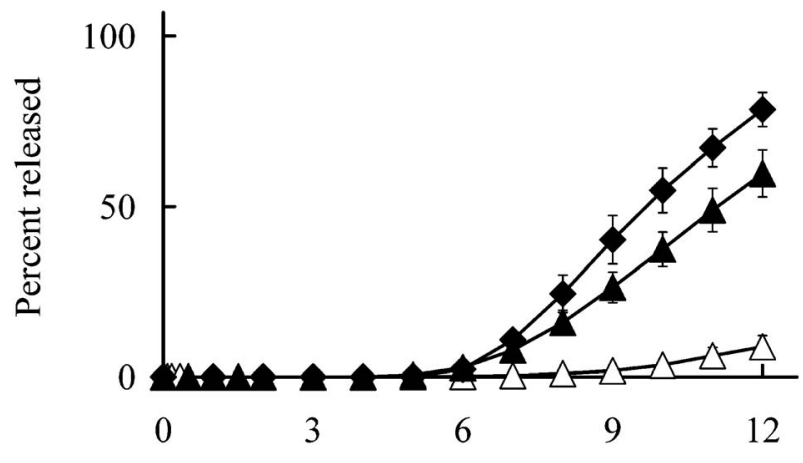

Time (h)

Fig. 2. Drug Release Profiles of 5-FU from OSDrC (Eud-L : Chit $=3: 1$ ) in Test Medium

Each data point represents the mean \pm S.D. of three measurements. Test medium: $(\triangle)$ 1st fluid $(\mathrm{pH} 1.2),(\boldsymbol{\Delta})$ hydrochloric acid aqueous solution with $0.2 \% \mathrm{NaCl}(\mathrm{pH} 3.0),(\diamond)$ phosphate buffer $(\mathrm{pH} 4.7)$.

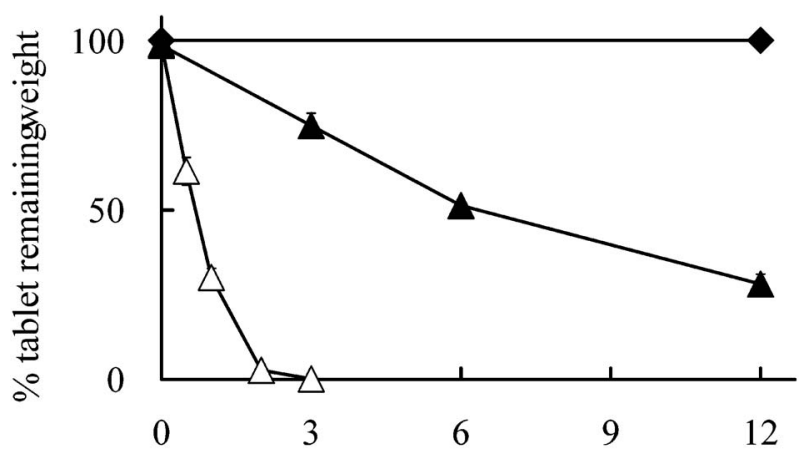

Time (h)

Fig. 3. Change in Weight of Tablets Consisting Only of Outer Layer (Eud-L : Chit $=3: 1$ ) in Test Medium

Each data point represents the mean \pm S.D. of three measurements. Most error bars are included in symbols because of small value. Test medium: $(\triangle)$ 1st fluid $(\mathrm{pH} 1.2),(\boldsymbol{\Delta})$ hydrochloric acid aqueous solution with $0.2 \% \mathrm{NaCl}(\mathrm{pH} 3.0),(\diamond)$ phosphate buffer $(\mathrm{pH} 4.7)$.

容排泄時間以上抑制された。

この $\mathrm{pH}$ 範囲では Eud-L は溶解せず，Chit のみ が反応する。そこで, pH が Chit の溶解に与える 影響を評価するため，Chit のみを圧縮成形した無 核錠の質量減少を経時的に測定し, Fig. 3 に示し た。第 1 液では Chit は溶解し， $3 \mathrm{~h}$ で消失した。こ れに対し, pH 4.7 では試験液投入直後に膨潤した ものの, $12 \mathrm{~h}$ でも溶解挙動はみられなかつた。 $\mathrm{pH}$ 3.0 では $12 \mathrm{~h}$ で $72 \%$ 溶解したが，膨潤挙動も確認 できた。したがって，Chit の溶解により生じた細 孔から薬物が放出される第 1 液に対し, $\mathrm{pH} 4.7$ で は溶解せず膨潤の夕であり，その形成された膨潤層 
から薬物は放出されるため, lag time に差が生じた ものと推察した。 pH 3.0 については，Chit は溶解 も膨潤もするが，その膨潤は試験液投入直後に確認 できたことから, 溶解速度は膨潤速度と比較して律 速であると考えられ，pH 4.7 と同様に薬物は形成 された膨潤層から放出されると推察した.

次に, より生体内の条件に近づけるために, 試験 液を 1 種類ではなく，連続的に変更させ，薬物放出 挙動を評価した。 Figure 4 に示したように，結腸を 想定した第 2 液における薬物放出挙動に差が生じた ものの，胃，及び小腸を想定した試験液で薬物放出 を抑制できた。試験液 1 種類の場合と異なり， $\mathrm{pH}$ 3.0 は pH 4.7 と比較して第 1 液に近い挙動を示し た．Chit はゲル形成後に溶解するため，第 1 液, あるいは $\mathrm{pH} 3.0$ に投入 $3 \mathrm{~h}$ で外層内にはゲル若し くは溶液状態の Chit が存在する。この状態で小腸 を想定したリン酸塩緩衝液（pH 7.4）に移すと, Chit が固体からではなくゲル若しくは溶液状態か ら膨潤するため，固体からのものと比較して，膨潤 速度が上昇し，結果として試験液の浸透速度の低下 に加えて，Eud-L 溶解速度が低下したことによ り，第 1 液，あるいは $\mathrm{pH} 3.0$ では固体から膨潤す る pH 4.7 と比較して lag time が延長し，第 2 液に おける薬物放出速度も低下したものと推察した。 Chit 膨潤層の形成様式により，試験液の浸透性に

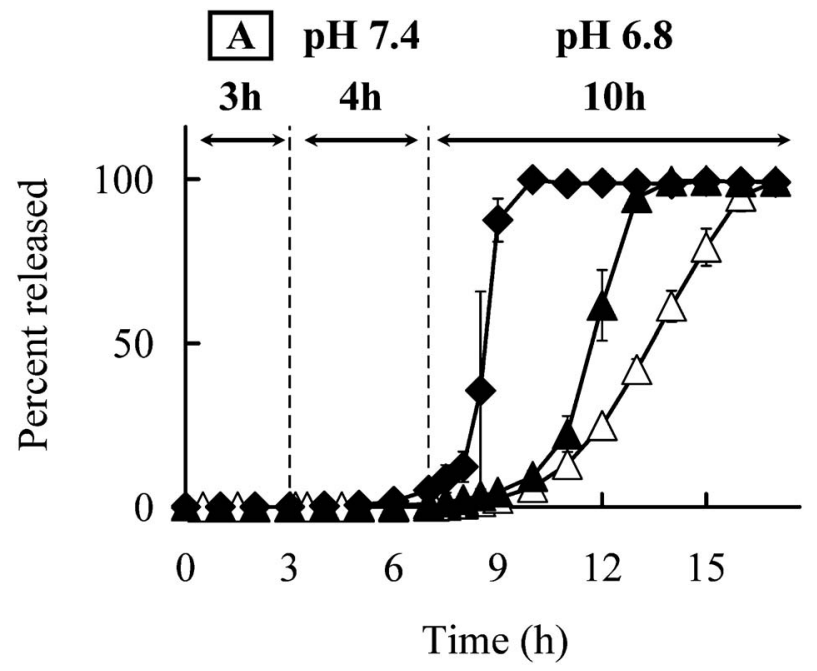

Fig. 4. Drug Release Profiles of 5-FU from OSDrC (Eud-L : Chit $=3: 1$ ) in the Sequential $\mathrm{pH}$ Change Method

Each data point represents the mean \pm S.D. of three measurements. Test medium A: $(\triangle)$ 1st fluid $(\mathrm{pH} 1.2),(\mathbf{\Delta})$ hydrochloric acid aqueous solution with $0.2 \% \mathrm{NaCl}(\mathrm{pH} 3.0),(\diamond)$ phosphate buffer $(\mathrm{pH} 4.7)$.
加え, Eud-L 溶解速度も変化することで, 外層全 体の透過性に差が生じると考えられるため, lag time，及び薬物放出速度は Chit 膨潤層形成様式の 影響を受けることを示唆した。

以上，調製した OSDrC は胃内酸度の影響を受け るものの，薬物放出は胃内容排泄時間以上抑制さ れ，さらに試験液を連続的に変更させても同様の結 果が得られたことより，低酸症・無酸症患者への使 用も可能であることを示唆した。

2. 界面活性剤の影響 小腸を想定したリン酸 塩緩衝液（pH 7.4）において， Eud-L は溶解し， Chit は溶解せずに膨潤することから，調製した OSDrC の薬物放出挙動には Eud-L が溶解したこと により生じた細孔，及び Chit の膨潤が関与してい

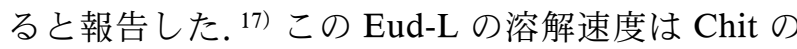
膨潤速度と比較して律速であることから，さらに検 討を重ねた結果，Chit の膨潤層により，Eud-Lの 溶解速度が遅延し，結果的に試験液の浸入が抑制さ れる. その後, 外界面の Eud-L が徐々に溶解し, 残存した Chit の膨潤層は強度が低下し浸食され， 最終的にエッジ部分に crack が生じ，薬物は放出さ れることを確認している.

十二指腸には胆汁が肝臓から胆囊を経て分泌され る。肝蔵からは 1 日に $0.3-1.0 \mathrm{~L}$ の胆汁が分泌さ れ，その胆汁中に含まれる胆汁酸濃度は 3.0-45.0 $\mathrm{mmol} / \mathrm{l}$ と言われている。 その界面活性作用は薬物 の水に対する濡れ性改善に寄与し，しばしば製剤か らの薬物放出挙動に影響を与える. ${ }^{19,20)}$ Eud-L の溶 解，あるいは Chit の膨潤も同様に影響を受ける可 能性があることから，調製した OSDrC の薬物放出 挙動も胆汁酸の影響を受けると考えられる。そこ で，調製した OSDrC に対する界面活性剂の影響を 評価するため，小腸を想定したリン酸塩緩衝液 （pH 7.4）に胆汁酸塩を溶解させた試験液を用い溶 出試験を行った。胆汁酸塩には，コール酸ではな く，より界面活性作用の強い DC を用い，0.01， $0.1,0.5,1.0 \%(0.24,2.4,12.1,24.1 \mathrm{mmol} / \mathrm{l})$ 溶解さ せた。その結果を Fig. 5 に示した。 DC\%上昇に伴 い lag time は延長し，薬物放出は小腸通過時間以 上抑制された。

ここで，DC が外層の浸食挙動に与える影響を評 価するため, Eud-L のみ, 及び Eud-L : Chit $=3: 1$ を圧縮成形した無核錠の $0.01,1.0 \%$ DC を溶解し 


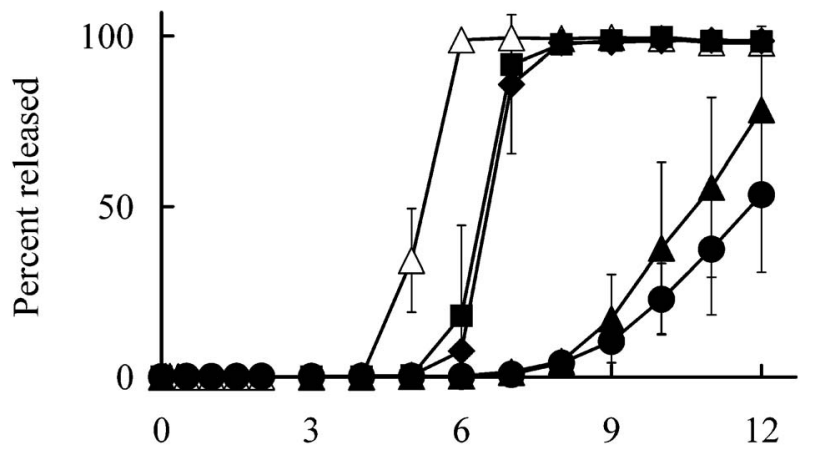

Time (h)

Fig. 5. Drug Release Profiles of 5-FU from OSDrC (Eud-L : Chit $=3: 1$ ) in Phosphate Buffer ( $\mathrm{pH} 7.4)$ with DC

Each data point represents the mean \pm S.D. of three measurements. DC concentration: $(\triangle) 0 \%,(\square) 0.01 \%,(\diamond) 0.1 \%,(\boldsymbol{\Delta}) 0.5 \%,(\bullet) 1.0 \%$.

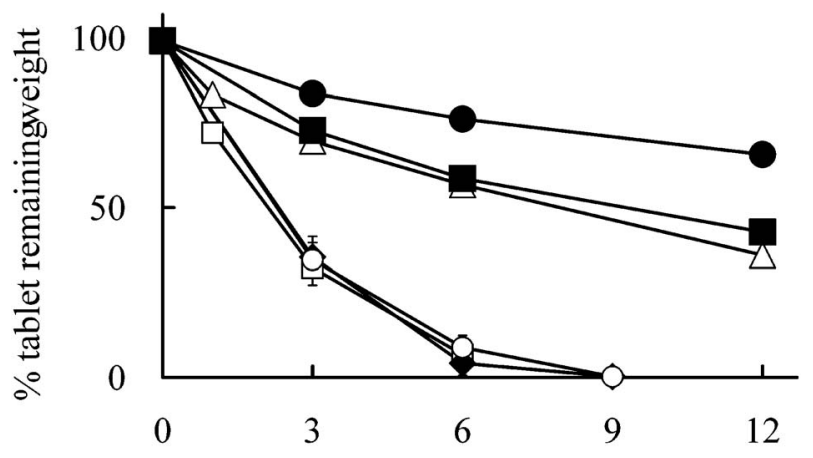

Time (h)

Fig. 6. Change in Weight of Tablets Consisting Only of Outer Layer in Phosphate Buffer ( $\mathrm{pH} 7.4$ ) with DC

Each data point represents the mean \pm S.D. of three measurements. Most error bars are included in symbols because of small value. Formulation and DC concentration: ( $\square$ ) Eud-L only, 0\%, ( ) Eud-L only, 0.01\%, (O) Eud-L only, $1.0 \%,(\triangle)$ Eud-L : Chit =3:1, $0 \%$, (ロ) Eud-L : Chit $=3: 1$, $0.01 \%$, (O) Eud-L : Chit $=3: 1,1.0 \%$.

た $0.05 \mathrm{~mol} / 1$ リン酸塩緩衝液（pH 7.4）における 質量減少を経時的に測定し, Fig. 6 に示した. EudL のみでは DC\%上昇に伴い質量減少率は低下し, 界面活性剂による Eud-L の溶解速度促進はみられ ず，逆に溶解は抑制された。同様に行った Chit の みでは DC 添加に係わらず，質量減少はみられなか ったことから，DCにより Eud-L の溶解速度が低 下したため, lag timeが延長したと推察した。 また,

Eud-L : Chit=3:1 では Eud-L のみ同様, DC\%上 昇に伴い質量減少率は低下したがその挙動はより顕 著であった。これは $\mathrm{DC} \%$ 上昇に伴い試験液の粘度 が上昇したことにより，試験液のChit の膨潤層へ の浸透速度が低下したためと推察した。したがって,
DC\% 上昇に伴う lag time の延長は DC による Eud$\mathrm{L}$ 溶解抑制，及び試験液の Chit の膨潤層への浸透 抑制によるものと推察した。さらに，DC を含有す るリン酸塩緩衝液（pH 7.4）が付着した状態の OSDrC を，結腸を想定した第 2 液へ移行した場合に おいても，外層内に少量ながら DC を含有するた め，前述の抑制効果は起こり得ると考えられ，lag time の延長，及び第 2 液における薬物放出速度の 低下が起こるものと推察できる.

以上より，調製した OSDrC は界面活性剂の影響 を受けるものの，薬物放出は小腸通過時間以上抑制 されたことから，胆汁酸の存在する小腸において薬 物溶出を抑制可能であることを示唆した.

3. 試験液量の影響 結腸は水分の吸収能力の 高い部位である。1 日 $2000 \mathrm{ml}$ の電解質液が回盲弁 から結腸に入り，水分の $90 \%$ 以上が結腸から吸収 される7) ため，水分のそしい部位とも言える．調製 した OSDrC の結腸を想定した第 2 液における薬物 放出メカニズムは，小腸を想定したリン酸塩緩衝液 （pH 7.4）のものと同様と考えられるため，水分量 減少により, 薬物放出量の低下のみではなく, Eud$\mathrm{L}$ 溶解速度低下, Chit 膨潤量低下も起こり得る. したがって，調製した OSDrC の薬物放出挙動は結 腸内水分量の影響を受けると考えられる。 そこで, 結腸を想定した第 2 液の液量を， $900 \mathrm{ml}$ から測定 可能な最小量として $10 \mathrm{ml}$ に減少させて薬物放出挙 動を評価した。その結果を Fig. 7 に示した。試験 液量の減少により, lag time が $5 \mathrm{~h}$ から $6 \mathrm{~h}$ に延 長，及び薬物放出速度が低下したものの, 結腸通過 時間（20-35 h）以内に薬物は完全に放出された. lag time の延長，及び薬物放出速度の低下は，試験 液量の減少，及びかく汼を行わなかったことによ り，試験液の浸透速度が低下し，その結果 Eud-L 溶解速度が低下し，外層全体の透過性が低下したた めと推察した.

次に, より生体内の条件に近付けるために, 試験 液を 1 種類ではなく，連続的に変更させ，薬物放出 挙動を評価した. Figure 8 に示したように，試験液 量の減少，及びかく拌を行わなかったことにより結 腸を想定した第 2 液における薬物放出速度が低下し たものの，lag timeに差は生じず，薬物は完全に放 出された。試験液 1 種類の場合と異なり, lag time に差が生じなかったことから，第 2 液への移行前に 


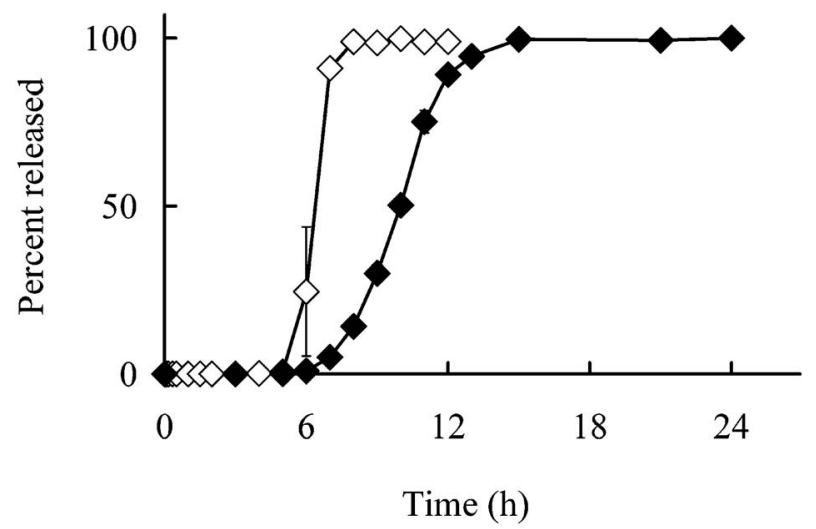

Fig. 7. Drug Release Profiles of 5-FU from OSDrC (Eud-L : Chit $=3: 1$ ) in the 2nd fluid ( $\mathrm{pH} 6.8$ )

Each data point represents the mean \pm S.D. of three measurements. Volume and rotation speed: $(\diamond) 900 \mathrm{ml}, 50 \mathrm{rpm},(\diamond) 10 \mathrm{ml}, 0 \mathrm{rpm}$.

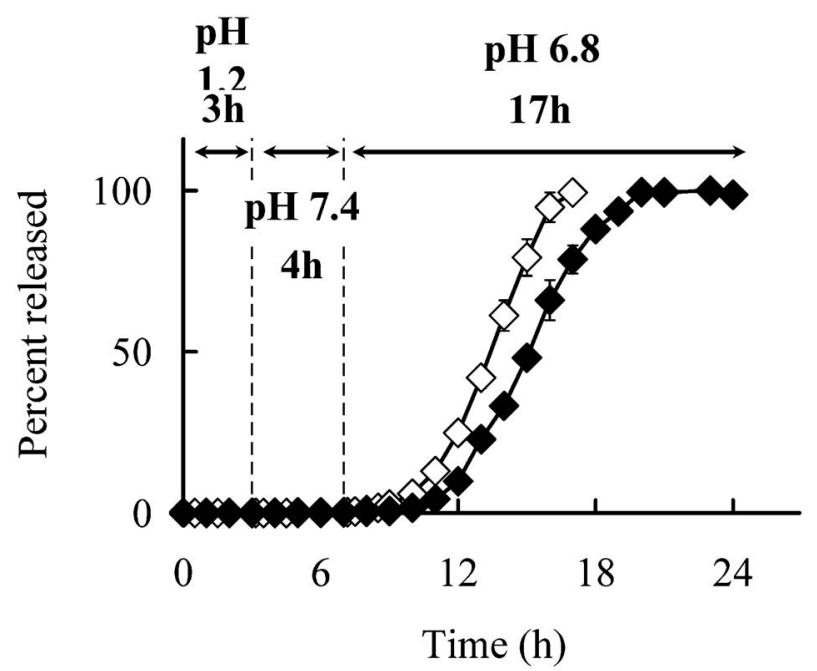

Fig. 8. Drug Release Profiles of 5-FU from OSDrC (Eud-L : Chit $=3: 1)$ in the Sequential $\mathrm{pH}$ Change Method

Each data point represents the mean \pm S.D. of three measurements. Volume and rotation speed of 2nd fluid (pH 6.8): (১) $900 \mathrm{ml}, 50 \mathrm{rpm},($ $10 \mathrm{ml}, 0 \mathrm{rpm}$.

試験液はほぼ Core へ到達していたと考えられ，そ の後の薬物放出が試験液量の影響を受けたと推察し た。したがって，胃を想定した試験液を前述の低酸 症・無酸症を想定した pH 3.0, 4.7 に変更させた場 合においても, Fig. 4 における pH 3.0, 4.7 の lag time が第 1 液の場合と比較して短いことから，第 2 液（10 ml）へ移行前に試験液はほぼ Core に到達し ていると考えられ, lag time は試験液量の影響を受 けず，放出速度の低下のみが起こるものと推察でき る.

以上, 調製した OSDrC は結腸内水分量の影響を 受けるものの, 結腸通過時間以内に薬物は完全に放
出され，さらに試験液を連続的に変更させても同様 の結果が得られたことより, 水分量の低い結腸内に おいても薬物を十分に放出可能であることを示唆し た.

\section{結 論}

調製した OSDrC は胃内酸度, 胆汁酸, 及び結腸 内水分量の影響を受けるものの, 胃を想定した試験 液で胃内容排泄時間以上, 小腸を想定した試験液で 小腸通過時間以上薬物放出を抑制し，結腸を想定し た試験液で薬物を放出したことから, 結腸ターゲテ イング製剤としての有用性が示唆された。

本研究において, 機械的破壊力の影響は評価して いない. 放出制御製剂の薬物放出挙動は, 消化管運 動に起因する機械的破壊力の影響を受けることが知 られているため, 今後は, 調製した OSDrC の機械 的破壊力に対する影響を評価する予定である.

\section{REFERENCES}

1) Ashford M., Fell J. T., Attwood D., Woodhead P. J., Int. J. Pharm., 91, 241-245 (1993).

2) Qi M., Wang P., Wu D., Drug Dev. Ind. Pharm., 29, 661-667 (2003).

3) Cheng G., An F., Zou M. J., Sun J., Hao X. H., He Y. X., World J. Gastroenterol., 10, 1769-1774 (2004).

4) Fukui E., Miyamura N., Uemura K., Kobayashi M., Int. J. Pharm., 204, 7-15 (2000) .

5) Pang Y. N., Zhang Y., Zhang Z. R., World J. Gastroenterol., 8, 913-917 (2002).

6) Xu C., Zhang J. S., Mo Y., Tan R. X., Drug Dev. Ind. Pharm., 31, 127-134 (2005).

7) Watts P. J., Illum L., Drug Dev. Ind. Pharm., 23, 893-913 (1997).

8) Hejazi R., Amiji M., J. Control. Release, 89, 151-165 (2003).

9) Raghavan C. V., Muthulingam C., Jenita J. A., Ravi T. K., Chem. Pharm. Bull., 50, 892895 (2002).

10) Zambito Y., Di Colo G., J. Pharm. Pharm. Sci., 6, 274-281 (2003).

11) Shimono N., Takatori T., Ueda M., Mori M., Higashi Y., Nakamura Y., Int. J. Pharm., 245, 45-54 (2002). 
12) Shimono N., Takatori T., Ueda M., Mori M., Nakamura Y., Chem. Pharm. Bull., 51, 620624 (2003).

13) Ozeki Y., Watanabe Y., Inoue S., Danjo K., Int. J. Pharm., 259, 69-77 (2003).

14) Ozeki Y., Watanabe Y., Inoue S., Danjo K., Int. J. Pharm., 267, 69-78 (2003).

15) Ozeki Y., Ando M., Watanabe Y., Danjo K., J. Control. Release, 95, 51-60 (2004) .

16) Ozeki Y., Watanabe Y., Okamoto H., Danjo K., Pharm. Res., 21, 1177-1183 (2004).

17) Sakurai M., Ozeki Y., Ando M., Okamoto
H., Danjo K., Yakugaku Zasshi, 127, 20572063 (2007).

18) Ogata H., Aoyagi N., Kaniwa N., Ejima A., Suzuki K., Ishioka T., Morishita M., Ohta K., Takagishi Y., Doi Y., Ogura T., J. Pharm. Dyn., 7, 656-664 (1984).

19) Shar V. P., Konecny J. J., Everett R. L., McCullough B., Noorizadeh A. C., Skelly J. P., Pharm. Res., 6, 612-618 (1989).

20) Fell J. T., Mohammad H. A. H., Int. J. Pharm., 125, 327-330 (1995). 